\title{
THE RIGHT TO COMPETE FOR PUBLIC EMPLOYMENT.*
}

George William Curtis stated the purpose of civil service reformers, as early as 1869 , in these words: "What we want is to intrench the principle and practice of Washington in the law." (II. Orations and Addresses, 9). The pioneer step to this end had been taken in Congress two years earlier, when Thomas $J$. Jenckes presented his report on the condition of the civil service, accompanied by a bill "to regulate the civil service of the United States and to promote its efficiency."

This early desire to embody the proposed reform in the law of the land found its first expression in the ninth section of the sundry appropriations bill of March 3, 187I. This measure authorizes the President "to prescribe such rules and regulations for the admission of persons into the civil service of the United States as will best promote the efficiency thereof, and ascertain the fitness of each candidate in respect to age, health, character, knowledge and ability for the branch of service into which he seeks to enter." It also authorized the President "to employ suitable persons to conduct said inquiries, to prescribe their duties, and to establish regulations for the conduct of persons who may receive appointments in the civil service."

This early recognition that the proposed reform must find expression in the law, shows how clearly its pioneers comprehended the nature of the mighty task to which they had set their hands. The story of what followed their first success in securing legal recognition of the reform-of the appointment by President Grant of an admirable commission headed by Mr. Curtis, of the active opposition by the spoilsmen, of the indifference of public sentiment, and finally in 1875 of the refusal of appropriations by Congress and consequent suspension of the rules-is too well known to require recounting here.

The early leaders of the reform movement, in seeking "to intrench the principle and practice of Washington in the law," made no mistake in the remedy for the monstrous evils of the spoils system. They failed for the moment sufficiently to real-

* Paper read before National Civil Service Reform League at Cincinnati, Ohio, December 17, 1897. 
ize that law, to be effective under free institutions, must be the command of popular opinion. However, to them the failure of the Act of $I 87 \mathrm{I}$ was only a repulse. They at once appealed from Congress to the people. By a few years of well-directed agitation they aroused and informed public opinion. The direct results were the national act of $x 883$, the New York act of the same year, the Massachusetts act of $\mathrm{r} 884$, the New York constitutional provision of I 894, the Illinois act of 1895 , and recent charter provisions of various cities. These achievements mark the progress of a rising and active popular sentiment in support of the merit system, which gives bright promise of its early extension to our entire civil service, national, state and municipal.

The legal situation is just now of peculiar interest. In Massachusetts, where the reform of course found a congenial atmosphere, it has been accepted as part and parcel of the orthodox faith. This happy result was not reached without some difficulty and even litigation. The appointing officers and the courts were for a time much perplexed by the veteran preference legislation; but a way has finally been found to recognize two privileged classes, women and veterans, under legislation the general purpose of which is to open public employment to the free competition of all. The Supreme Court in the case of Brown v. Russell, $x 66$ Mass. 14 , early in 1896 , held the act of 1895, which required the appointment of any veteran to any position for which he and three citizens of his selection might certify him to be qualified, to be unconstitutional. Thereupon, by act of 1896 , it was provided that veterans found to be qualified upon examination shall be preferred in appointment to all others, except women. The act also permits appointing officers to appoint or employ veterans without examination. This act the court by a majority of four to three has sustained, on the ground that the Legislature may have considered that veterans, otherwise qualified, are "likely to possess courage, constancy, habits of obedience and fidelity, which are valuable qualifications for any public office or employment; or that the recognition of the service of veterans in the way provided for by the statute would encourage that love of country and devotion to the welfare of the state which it concerns the commonwealth to foster." The minority of the court refuse to concede that the fact of being a veteran bears such relation to the duties of a present office or employment in the civil service that it can be made a decisive test in the selection of persons for employment, or that service in the army or navy in the late war is the only way to acquire 
special fitness for public employment. They say: "The important matter is to get the best possible service, and the selections should be made with reference to the qualifications or fitness for the performance of the duties which are to be performed. And, since this is so, it is not within the constitutional power of the Legislature to fix as a decisive test anything which does not bear such a relation to the duties to be performed as to show special fitness for the performance of those duties." It is evident that the act thus sustained has at least gone to the extreme limit in securing a class preference by law.

The legal situation in New York shows that the fully-evolved spoilsman is not awed even in the presence of a constitutional provision. The constitution of $\mathrm{I} 894$ requires that "appointments and promotions in the civil service of the State, and of all civil divisions thereof, *** shall be according to merit and fitness, to be ascertained, so far as practicable, by examination, which, so far as practicable, shall be competitive." The Court of Appeals, in the case of People $v$. Roberts, ${ }_{4} 8 \mathrm{~N}$. Y. 148, broadly says, "The principle that all appointments in the civil service must be made according to merit and fitness, to be ascertained by competitive examinations, is expressed in such broad and imperative language that in some respects it must be regarded as beyond the control of the Legislature, and secure from any statutory changes. If the Legislature should repeal all the statutes and regulations on the subject of appointments in the civil service, the mandate of the constitution would still remain, and would so far execute itself as to require the courts, in a proper case, to pronounce appointments made without compliance with its requirements illegal."

The same court, in the case of Chittenden $v$. Wurster, $I_{2} \mathrm{~N}$. Y. $345,35^{8}$, holds, that the question whether the examination of a candidate for a public position is practicable, is judicial and depends upon the nature and character of the duties of the position. This case presented the question whether a clerk to the committees of the Brooklyn board of aldermen, an assistant warrant clerk, a dockmaster, a chief clerk, a law clerk, a surveyor, a finance clerk, a license fee collector, a department secretary, a commissioner's clerk and a deputy license clerk, are within the constitutional provision, it appearing that they had been appointed without competitive examination. The plaintiffs produced a mass of evidence, including examination papers, reports and various civil service regulations, to show that competitive examinations for the appointments in question are prac- 
ticable. The defendants produced no evidence to show that they are impracticable. The trial justice held "that it was and is practicable to ascertain the merit and fitness of a person to be appointed to each of said positions by competitive examination." The Appellate Division of the Supreme Court held that "none of these appointees fall within the debatable class, but were plainly susceptible of being filled by competitive examination." (r4 App. Div. Reps. 497).

The Court of Appeals, by a majority of four to three, reversed the lower courts, holding generally, that where the duties of a position are not merely clerical, and are such as especially devolve upon the head of the office, which, by reason of his numerous duties, he is compelled to delegate to others, the performance of which require skill, judgment, trust and confidence, and involve the responsibility of the officer or the municipality which he represents, the position should be treated as confidential. (I52 N. Y. 360 ).

The conclusion of the majority of the court was strongly contested in dissenting opinions by Judges Gray and O'Brien, in the first of which Chief Judge Andrews concurred. They pointed out that the six Justices below were unanimous in finding, upon uncontradicted evidence, that it was practicable to fill all the places in question by competitive examinations, and that "the obvious effect of the constitution was to remove the eleven places in question from the non-competitive schedule since it was practicable to fill them all by competitive examination." ( $5_{2}$ N. Y. 386, 393). Judge O'Brien, in his very able dissenting opinion, correctly stated the situation in these words: "The future of the law which now rests upon the basis of the constitu. tion is dependent upon the decision of this court. The decision in this case will either place the reform upon a reasonable and just basis, and command the approval of all good men, or it will be a step backward." (Id. p. $3^{89}$ ). While the majority of the court frankly announce that, "should time and experience prove that we are in error * * * we shall not hesitate to carry out the spirit and intent of the law." (Id. p. 360), it is to be remembered that the Court of Appeals must alone determine what the spirit and intent of the constitution require.

The prevailing opinion in the Chittenden-Wurster case must be regarded as a loose construction of the constitutional requirement that appointments and promotions shall be according to merit and fitness, to be ascertained by competitive examination, so far as practicable. It is "a step backward," by a great court 
which had from the outset led in judicial support of the merit system. In the presence of a judgment so favorable to the spoilsmen, resting as it does upon the opinion of four of the Judges, against tnat of three others unanimously supported by the six Justices of the Supreme Court who passed upon the case below, the Court of Appeals can no longer truly say what it said in the Roberts case in speaking of the reform: "This court, upon more than one occasion, has, with entire unanimity, expressed its approval of the principle, and exercised all of its powers in every proper case in aid of all laws intended to carry out the idea." ( $148 \mathrm{~N}$. Y. $3^{64}$ ). If the majority opinion of the court is finally to prevail, the constitutional provision of $\mathrm{New}$ York, requiring competitive examinations so far as practicable, falls far short of the Illinois statute which provides that all applicants for positions in the classified service. from which but few places are excluded, "shall be subjected to examination, which shall be public, competitive and free to all citizens of the United States, with specified limitations as to residence, age, health, habits and moral character."

The Legislature of New York, under an irresponsible dictatorship, has persistently neglected, since the adoption of the constitutional provision of 1894 , to provide appropriate legislation to give it full and affirmative effect, as commanded by the constitution itself. This neglect was emphasized by the passage, at the last session, of a act providing for two examinations to ascertain the "merit and fitness" of candidates for appointment, one by the civil service commission to determine their relative "merit," and one by, or under the authority of, the appointing officer to satisfy him as to their "fitness." Each examination is to cover one-half of the rating of candidates. It is not in fact required that the so-called "examination" to ascertain "fitness" shall be competitive, or that it shall be public or made matter of record. It may be conducted by "some person or board designated by the person holding such power of appointment." In plain words, this so-called examination may be held at the party headquarters, on the street, or in the corner saloon, and may be conducted by a political committee, the party boss, or a convenient barkeeper. Mr. Schurz, in his powerful address of protest to the Governor, properly suggested that holding two examinations to ascertain "merit and fitness" is like requiring two examinations by physicians to find whether one is "hale and hearty," one as to whether he is "hale" and the other as to whether he is "hearty." 
The act in question is the clumsy device of spoilsmen to nullify the constitution of the State. That a conspiracy so transparent and subversive of public order can succeed is of course impossible. There is nothing in the history of the courts of New York to give any promise of success to an unlawful purpose so obvious. In the prevailing opinion in the ChittendenWurster case, written after the passage of this measure, the Court of Appeals significantly said: "It is said that each officer having appointments to make could himself examine the applicants for position, and in that way determine who should be the appointee by a competitive examination. Undoubtedly, but it will readily be seen that this system would practically nullify the civil service law and bring it into disrepute." ( $5_{5} 2$ N. Y. p. 356).

The submission of the "Black Bill" to the scrutiny of the courts, which is soon to be made, can have but one result. The certain defeat of this transparent attempt to nullify the constitution ought to prepare the way for the legislation which it commands.

The change of administration in Chicago last April has subjected the Illinois statute to a crucial test. Unfortunately, the act did not go into effect until the July foliowing its adoption at the city election of 1895 . That election resulted in a change from democratic to republican control. The new Mayor promptly turned out "the gang,"as his followers not inappropriately called the democratic host, and installed "the boys," who were expected to control in his interest the republican machine, now euphoniously known as "the organization." This clean sweep and substitution even extended to some six hundred mem. bers of the police force. Having thus strikingly illustrated the need, and prepared the way, for reform, Mayor Swift appointed an excellent commission and thereafter cordially supported it. This seeming inconsistency on his part is perhaps traceable to a desire to mark the introduction of the merit system by a conversion as dramatic as that of St. Paul. Possibly he sought at the outset of his administration to put temptation behind him, or to create a sort of solitude in which the new commission might learn its duties and formulate the rules required by law. Whatever the truth, the Mayor thereafter sustained the commission while it worked out a thorough classification of the service, prepared adequate rules, held many examinations and certified a few eligibles for appointment. Under such conditions came the change from republican to democratic rule in the election of 
Wayor Harrison last spring and a clean sweep of Mayor Swift's personal appointees.

The Inlinois statute is based on the national, New York and Massachusetts acts. It differs from the earlier legislation in that it is more inclusive and stringent in its provisions. The excluded "head or heads of any department" of the New York act gives place to the "heads of any principal department" in the statute of Illinois. Unrestricted removals under all prior legislation give way in Illinois to removals only for cause, to be ascertained upon written charges after opportunity to the person charged to be heard. The Illinois act also provides that vacancies shall be filled by promotion where it is practicable; that promotions shall be "on the basis of merit and seniority of service and examination," and that "all examinations for promotion shall be competitive."

The commissions under the Illinois statute are continuous and independent bodies. Mayor Harrison, however, assumed the Chicago commissioners to be his subordinates, and that a majority of them should be in political and personal accord with himself. Upon the refusal of the majority of the old commission (the other member having been appointed Comptroller) to accept his construction of the words, "heads of any principal department," used in naming the excluded officials, to include some fifty heads of bureaus in the departments, inspectors and captains of police and various foremen and others, the Mayor removed the two remaining members on frivolous charges afterwards trumped up to comply with a provision of the statute requiring him to file his reasons for such removals. The new commission promptly published an opinion construing the words, "heads of any principal department," so as to exclude from the classified service most of the desirable positions claimed by the Mayor as spoils, thus giving him (to use their words) "the benefit of the doubt"' as to the positions which "should be taken out of the classified service." The Mayor was thus enabled to fill the higher places in the service with arowed and active enemies of the merit system, an opportunity which he promptly improved. His appointees, with some honorable exceptions, in coöperation with the council, are doing what may be done to place the civil service law in a false light before the public, and -so far as practicable-to render it inoperative.

The statute excludes from the classified service "officers * * * whose appointment is subject to confirmation by the city council." When the act was adopted but few officials, some 
of them of minor importance, were subject to such confirmation: Upon the accession of Mayor Harrison it was feared by some of the best frienas of the law that it is especially vulnerable at this point. Its enemies quickly sought to avail themselves of their apparent opportunity. The council promptly created a considerable number of new positions, making them all subject toconfirmation by itself. The committee on civil service, on June I 4 , I897, reported forms for four ordinances, recommending their passage. By these measures it was gravely proposed to designate as " 'heads of principal departments,' as said term is used in section eleven" of the civil service act, numerous "public officials" and "all employes of the City of Chicago receiving three dollars or less per day, as compensation for work;" to make "the head of each and every department, bureau or division of work in the public service of Chicago," and certain experts, private secretaries, head assistants and others, subject to confirmation by the council; and to make all "transfers, appointments, discharges and promotions in the fire and police departments" subject to the order of the Mayor and approval of the council. These extraordinary proposals were opposed by the administration which was not prepared to attempt the complete nullification of the statute. Two weeks later the council passed, as an administration measure, an ordinance which provides that a considerable list of "officials" named "shall be designated as 'heads of principal departments,' as said term is used in section eleven" of the civil service act.

Some of the friends of the law, fearing these attacks were aimed at a vital point, deemed it wise to endeavor to save something by acquiescence. Others, and notably the Citizens' Association, held that the way to save the law was to defend it against all comers. The Citizens' Association retained special counsel and procured the Attorney-General to file petitions, on behalf of the people, in the Supreme Court for writs of mandamus to obtain an authoritative and final interpretation of the law, and of the power of the city council in respect to it. These cases were fully presented to the court in October last, and early decisions are expected. The new commission only contended for a liberal construction of the words, "heads of any principal department." The corporation counsel boldly attacked the constitutionality of the act, and defended the ordinance which seeks to make subordinate officials "heads of principal departments" merely by thus designating them. The writer's relation to these cases renders improper here any prophecy in regard to the 
result. It must suffice here to say, that we hope for a judgment by the court strongly sustaining the act, with a finding that the ordinance is void as unreasonable and in conflict with the statute.* The law is supported by public opinion." The penalties for its violation are severe. If fully sustained by the court, it will be at least reasonably enforced.

The President, by his executive order of July 27, I897, directing that removals shall be made only for just cause, upon writren charges and opportunity to be heard, has raised the question whether removals should be controlled by law. Civil service reformers have hesitated to place any legal restraint upon the power of removal by the appointing officer for any cause satisfactory to him. They have assumed that such officers will not be apt to remove efficient subordinates to make way for unknown successors to be taken from the eligible list. As early as $188 \mathrm{I}$, in his address before The American Science Association, Mr. Curtis said:

"Removal for cause alone means, of course, removal for legitimate cause, such as dishonesty, negligence or incapacity. But who shall decide that such cause exists? This must be determined either by the responsible superior officer or by some other authority. But if left to some other authority the right of counsel and the forms of a court would be invoked; the whole legal machinery of mandamuses, injunctions, certioraris, and the rules of evidence, would be put in play to keep an incompetent clerk at his desk or a sleepy watchman on his beat. Cause for the removal of a letter-carrier in the post-office or of an accountant in the custom house would be presented with all the pomp of impeachment and established like a high crime and misdemeanor." (II. Orations and Addresses, p. r9o).

Mr. Curtis, in his second annual address as President of the League in $x 883$, also said: "We do not plead for fixed permanence in public place, nor assert a vested right in public employment. Due subordination and discipline are essential to all effective organized service, and therefore, dismissal for proper cause should be prompt and sure. To this end the power of removal should be left as free as possibie, provided that motives for its illegitimate exercise are destroyed. Such a provision

* The Supreme Court of Illinois on December 22, 1897, handed down a strong opinion in these cases holding the statute to be constitutional and the ordinance in question void for unreasonableness. The court, in effect, holds that the council has no power to add to the list of exclusions from the act. This decision places the Illinois act on a firm basis. 
secures both proper discipline and a just tenure." (Id. p. 248). Again, in his sixth annual address, he saiä: "The power of removal no less than that of appointment is a public trust, and it cannot be rightly used arbitrarily or for any other cause than the public interest. Such cause should be publicly assigned and recorded, that the people may clearly understand the reason of the change in the service." (Id. p. 340).

These passages indicate what has been the generally accepted view of reformers. Aside from the prohibition of removals for political reasons, there was no attempt until recently to limit the power of removal by appointing officers. The framers of the Illinois act took the first step in advance by providing that "no officer or employe in the classified service **

* shall be removed or discharged except for cause, upon written charges and after an opportunity to be heard." From this provision laborers and "persons having the custody of public money, for the safe keeping of which another has given bond" are excepted. "Such charges shall be investigated by or before said civil service commission, or *** some officer or board appointed by said commission to conduct such investigation. The finding and decision of such commission, or investigating officer or board when approved by said commission, shall be certified to the appointing officer, and shall be forthwith enforced by such." (Act I895, Sec. 12).

These provisions, it will be observed, make no attempt to define what causes shall be sufficient to justify removals. It is not believed that the act confers upon those in the classified service any vested right to continue in public employment, or to call upon the courts to determine whether any alleged cause of removal, except it be political, is sufficient to justify it. The intention is to protect the classified service from arbitrary and unjust removals by appointing officers, and to prevent removals for other than causes that will bear public record, after opportunity to make defense. Under this act the commission is made publicly responsible for every removal from the classified service.

The question involved in the recent decisions of United States courts, whether the President's order in respect to removals has the force of law, is less important than the question whether it ought to have such force. The answer to the first depends upon the extent of executive power under the civil service act to make rules that shall have the force of law. The answer to the other must be sought in the further inquiry, 
whether public employment can be the subject of vested right, whether office is a place of public service, or a castle to be privately held and enjoyed.

The merit system of appointment recognizes and protects the right of all to compete for public employment, the right of freedom of contract with the largest employer of skilled and unskilled labor. The Massachusetts act provides for the punishment of officials and others who shall "defeat, deceive or obstruct any person in respect of his or her right of examination," (Sec. I8). The constitution of New York requires all appointments to be made upon "examination which, so far as practicable, shall be competitive." The Illinois act provides that "all applicants for offices or places in said classified service ** * shall be subjected to examination, which shall be public, competitive and free to all citizens of the United States, with specified limitations as to residence, age, health, habits and moral character." (Sec. 6).

The Supreme Court of Massachusetts, in the case of Commonwealth $v$. Perry, 155 Mass. $x 17$, said: "There are certain fundamental rights of every citizen which are recognized in the organic law of all our free American States. *** The declaration of rights in the constitution of Massachusetts enumerates among the natural, inalienable rights of men the right 'of acquiring, possessing and protecting property.' *** The right to acquire, possess and protect property includes the right to make reasonable contracts, which shall be under the protection of the law."

The Supreme Court of Illinois in the case of Braceville Coal Co. v. People, 147 I11. 66, 70, said:

"The fundamental principle upon which liberty is based, in free and enlightened government, is equality under the law of the land. It has accordingly been everywhere held, that liberty, as that term is used in the constitution, means not only freedom of the citizen from servitude and restraint, but is deemed to embrace the right of every man to be free in the use of his powers and faculties, and to adopt and pursue such avocation and calling as he may. choose, subject only to the restraints necessary to secure the common welfare."

The same court, in the great case of Ritchie $v$. People, $x_{55}$ Ill. 98, 104, also said: "The privilege of contracting is both a liberty and property right. *** The right to use, buy and sell property and contract in respect thereto is protected by the constitution. Labor is property, and the laborer has the same right to sell his labor, and to contract with reference thereto, as 
has any other property owner. * * * The right to labor or employ labor, and make contracts in respect thereto upon such terms as may be agreed upon between the parties, is included in the constitutional guaranty."

Thus it follows that the right of freedom of contract with the largest employer of labor, is a property right which is protected by the fundamental law (see also, Stimson's "Handbools to the Labor Law of U. S.," pp. ro, etc.); that all citizens, having the proper requirements of age, health and character, have a property right to compete for public as well as private employment. It is the great purpose of the merit system of appointment to give force and effect to this fundamental right of free men.

We are now ready for the inquiry, whether the right to compete for public employment extends, on behalf of the successful competitors, beyond the threshold of such employment, there to become a vested property right in the office itself. Unless offices exist to be held, the answer must be in the negative. A fundamental principle of civil service reform is that public office is a public trust. It is an opportunity to render a public service, and whatever of personal honor and profit attach to it is but incidenta1. The public has a right to the most efficient and devoted service, and to this end to continue competent and faithful officials in its employment. Thus the public need, not personal interest, becomes and is the basis and measure of a just tenure. Only in this view can "the public service be, indeed, the public service" (Gladstone)-the property of the nation, not an asset of a party boss or machine.

We inay, therefore, conclude that the right to compete for public employment is a property right of all; that this right is part and parcel of the fundamental right of freedom of contract; that a right of such importance ought to be given full force and effect by positive law. We have seen that this is the purpose of all civil service legislation. It also follows that public office is not properly a subject of vested right; that official position is an opportunity for public service, not a private property interest: and that its control is an executive, not a judicial, function. If these conclusions are sound, it remains for the executive to prevent removals except for just cause. It does not follow that the President's order is less wise because it is not properly enforceable by the courts. It will be to the lasting honor of the present administration if it shall firmly establish a rule of executive action to prevent removals without just cause. 
The evolution of modern democracy is from the simple and primitive groups of kinsmen, known to us as village communities. The crude democracy of these isolated communities gave way to the despotic feudal monarchy which welded them into the great nation having a definite territory, uniform laws and comparative freedom from local disorder. Then came the long struggle for a democracy which should combine the great advantages of a wide national authority with as much as practicable of the local self-government and personal freedom of the village community. This struggle is marked by a long succession of popular victories over despotic privilege. The spoils system in our day is a mercenary survival of feudal privilege. Its destruction will remove another barrier from between the people and their government. The merit system, in its purpose "to intrench the principle and practice of Washington in the law," seeks to recover a fundamental right of free men. To such a purpose, complete success is sure. It may be here and there delayed, but it will come.

Edwin Burritt Smith. 